\title{
An Approach to Reggaeton's Songs: A Co-Educational and Pedagogical Proposal with Teenagers
}

\author{
Sandra Soler Campo ${ }^{1}$ \\ ${ }^{1}$ University of Barcelona, Faculty of Education, Barcelona, Spain \\ Correspondence: Sandra Soler Campo, Faculty of Education, Campus Mundet, University of Barcelona, Passeig \\ de la Vall d'Hebron, 171, 08035, Barcelona, Spain. E-mail: Sandra.soler@ub.edu
}

Received: November 28, 2019

Accepted: March 1, $2020 \quad$ Online Published: June 5, 2020

doi:10.5539/ies.v13n7p12

URL: https://doi.org/10.5539/ies.v13n7p12

\begin{abstract}
Currently there is a great variety of musical styles that coexist in our society. We can access music in very different ways and with immediacy never before imagined. For teenagers, music is a key element in defining their identity, socializing and taking refuge in their inner world.

This communication focuses on the analysis of songs from the Reggaeton music genre and the way in which students receive them. The co-educational proposal carried out in a private secondary school in Barcelona will be explained. Its main objectives will be, on the one hand, to foster a critical spirit in the students towards these types of songs and, on the other hand, to offer an education in terms of equality that deconstructs myths and stereotypes.
\end{abstract}

Keywords: teenagers, stereotypes, coeducation, society

\section{Introduction}

Music occupies a very important space in the lives of adolescents due to the multiple functions it plays. From altering moods, shaping aspects related to personal identity, establishing to strengthening interpersonal relationships. In many cases, music can even influence the consolidation of gender identity. A clear example is the messages that song lyrics of certain popular urban music contain, which will be key in the transmission, assertion or breakdown of the different stereotypes linked to a certain society and culture. It is also one of the tools most used by teenagers in their daily lives to achieve different essential objectives such as changing moods, relating, shaping their own identity, etc. (Oriola \& Gustems, 2015). The widespread use of music can become another variable in terms of the configuration of the adolescent personality (Miranda, 2013).

Adolescents can be particularly sensitive and receptive to messages that contain these topics such as love, lack of love or sex. A variety of these issues is treated directly or is strongly involved in the content of the lyrics of songs.

The preference for certain musical styles is more intense during adolescence than during childhood. An adolescent's view of himself or herself may be related to previous musical experiences, social interactions, school, culture, and previous life experiences. Musical preference, which is often part of an adolescent's identity, often changes with age, mood, social status, or many other circumstances that are constantly changing.

Most of the lyrical content, which concerns many critics, is concentrated on a few musical genres such as rap, trap and reggaeton. The lyrics of the songs belonging to these musical genres usually contain negative messages which are received by the different users who listen to them directly and/or indirectly. Lyrics have undergone dramatic changes since the introduction of reggaeton music in society in recent years. This is an issue of significant interest and concern for parents and educators (Strasburger, 1995). Over the last few decades, the lyrics of reggaeton music have become increasingly explicit, especially with regard to sex, gender discrimination and violence. In some cases, song lyrics convey potentially negative messages in which the female sex is treated as inferior and submissive. Such lyrics are of particular concern in the current environment as they pose serious and unprecedented threats to social relations among adolescents. Thus, these are the biggest consumers of this music style.

Videos and Audio-visual media are popular with children and adolescents. When music lyrics are illustrated in music videos, their potential impact is magnified. Teenagers who don't "hear" or those who are not aware of the 
lyric's content, can see the images that appear in most of them. In addition, music videos reinforce themselves as they often contain excessive sexism, violence, substance abuse and inappropriate sexual behaviour. In addition, new technologies have made it possible for humanity to be exposed to all kinds of music constantly and to greater immediacy than ever before. Adolescents, who spend much of their daily lives listening to music or watching music videos, are not an exception. Thus, music is a key socio-emotional element in every adolescent's life due to its multi-functionality: it helps them to shape their identity, to relate to their peers, to self-regulate their state of mind... For all these reasons, the messages transmitted (directly and indirectly) by commercial songs such as trap, hip-hop, reggaeton music can have a great impact on the behaviour, experimentation and regulation of their emotions.

Miranda (2012) argues that music can be very influential in the development of adolescents, especially in areas such as socialization, control and development of emotions, personality, motivation, and positive development. While during childhood, one is open to listening to different kinds of music, adolescents have developed a definite preference for certain musical styles. Lamont and Webb (2010) assert that adolescence is a critical period for developing ingrained musical preferences. Many teenagers identify with others who like the same music. They often organize themselves into groups whose nexus are their musical preferences. Many teens have also the need to fit in and be socially accepted, so their musical preferences may change depending on their personal and social situations (North \& Hargreaves, 1998).

Nowadays, a significant number of song lyrics contain some kind of sexual reference. Users tend to accept the media they receive without questioning it. Therefore, representations of the sexual media can alter our criteria used in forming opinions. This means that such media can help us to favour the sexual qualities of one gender over other qualities (Carpentier, 2014). Artists of reggaeton, trap and rap music, in particular, tend to use derogatory and degrading lyrics towards women to increase their masculinity (Adams, 2006).

Neuromusicology research focused on adolescents is still a field to be investigated. More so if we compare it with the large number of research studies carried out focused on children, or adults (Edwards \& Hodges, 2007). This fact is mainly due to the lack of interest on the part of adolescents to participate in studies. This type of analysis, studies and research is necessary to deepen the understanding of the relationship between music, adolescence and brain function. Some studies indicate that the prefrontal regions of children and the brains of adolescents have a less mature response compared to adults (Casey et al., 2002). This information provides an explanation of the decisions adolescents make, including their musical preferences. However, it should be noted that there are individual differences and these results cannot be generalized. Neuroscience has shown that music listening and creation involves multiple areas of the brain, either simultaneously or in intricate, interrelated, and surprisingly rapid sequences (Hyde et al., 2009).

Coeducation, understood as the education that promotes gender equality without discrimination of any kind (Simon, 2010) will be of great importance in orienting and providing activities to young people that break down all kind of stereotypes. In schools, the task of all the members which are part of the educational community and the educational system in general is to promote policies and learning based on avoiding the reproduction of such roles. To this end, and following Contreras and Trujillo ideas (2014), it is necessary to carry out gender studies that allow us to discover and question the stereotypes and, to propose possible co-educational solutions that can be extrapolated to everyday life.

\section{Objectives}

Following the Compulsory Secondary Education curriculum, the general objective to be achieved with the execution of the following pedagogical proposal is:

- To analyze the different sexual stereotypes based on various didactic proposals.

This objective will be pursued through the following actions:

- To examine different songs that contains sexist language and stereotypes in the lyrics.

- To establish alternatives to such messages by substituting them with others that are more appropriate and that do not discriminate against the female sex.

- To reflect on the possible repercussions that these messages generate in our society being able to confront it in a critical way and looking for alternatives.

- To respect the variety of opinions and points of view that may arise from the carrying out of the activities and the subsequent discussion. 


\section{Method}

The methodology used to carry out this research consists of a non-experimental ex post facto, exploratory, descriptive and comparative methodology. Based on the results obtained by carrying out different co-educational activities with students of Compulsory Secondary Education, it is intended to recognize the phenomenon of possible sex discrimination in the lyrics of reggaeton songs.

\subsection{Participants}

The active agents who have participated in this research are 100 students in the 3rd year of Compulsory Secondary Education in Barcelona. It is an educational institution made up of three lines. Therefore, each session has been carried out in three classes of 33/34 students each. In order to achieve the objectives set out above, four sessions of 60 minutes were necessary.

Of the 100 participants, $45 \%$ are male and $55 \%$ female. Of all of them, $12 \%$ carry out some kind of musical activity outside the school as extracurricular activity in conservatories, music schools ... Of this $12 \%$, the female presence predominates $(10 \%)$. They are all between 14 and 15 years old.

\subsection{Materials}

Several computers with Internet connection and headphones will be required. Also some paper support (notebook, blank pages) and several post-its.

\subsection{Analysis of the Results}

First, students are asked whether they have ever heard a song in which they have identified a sexist message, inappropriate gender vocabulary, or a song in which women are treated in a derogatory manner. After this first initial question, which will try to establish a discussion among the students, the influence of language and the messages and the messages that contain certain songs are debated. It will also seek to identify in which musical genres this occurs most frequently.

Afterwards, the group/class will be divided into groups of 4-5 students and they will search on Internet the lyrics (video if possible) that the teacher proposes. They must listen to them, read the lyrics, identify the sexist messages they contain, and discuss them with their classmates in a small group. Then they will copy the lyrics of the songs and point out or underline the words that seem inappropriate for them. Then, on a post-it they should write down the different expressions, ideas, words, sentences...that have caught their attention because of their sexist, derogatory and/or inappropriate content in order to replace them with alternative expressions that they consider to be more appropriate and free from sexist messages. They should also write down why they have chosen certain phrases and what they think about them so that they can discuss them later.

All the post-it (from all groups) will be hooked on a mural. Finally, there will be a debate between the whole group/class to comment on what has surprised them, what they have highlighted, their ideas, etc.

The songs that have been analyzed in this activity are the following:

- Against the wall by Jiggy Drama

- The spanking by Alexis i Fido

- In Daddy Jankee's bed ft. Nicky Jam

- That in four is not seen by Lui G

- You're mine by Romeo Santos

- Lollypop by Kidd Keo

- Bitch by Elilluminari

- Four Babys by Maluma

- If I behave badly by Dasoul

- You're mine by Bad Bunny

\section{Analysis}

The following are the sentences that the students have highlighted, and the proposals for change that they have made. In addition, the opinions of the students have been taken into account and are included at the end of the analysis of each song.

\section{Against the wall by Jiggy Drama}


You're not going to reveal yourself to me.

or I'll give you your punishment (...)

If you continue with that attitude, I'm gonna rape you. Hey.

\begin{tabular}{|l|}
\hline You're not going to reveal yourself to me. \\
\hline You're not staying with me \\
\hline
\end{tabular}

\begin{tabular}{l} 
If you continue with that attitude, I'm gonna rape \\
you. \\
\hline Stop behaving like this. \\
\hline
\end{tabular}

The underlined phrases are the ones that have caught our attention the most. The first one "You will not reveal yourself to me or I'll give you your punishment" indicates that if the girl does not listen to the boy and does not do what he says, he will punish her. The girl doesn't have to do what he tells her and he has even less of a right to "punish" her as if she were a pet or something. Also, the fact that she can't reveal herself indicates that she might be doing something compulsory, which isn't right; no one should force anyone to do something they don't want to do.

The second sentence, "If you continue with that attitude, I'm going to rape you". It seems to us to be one of the most obscene and denigrating to use. No matter what attitude a person has, no matter what he or she may have done to you. To rape is not a game; it's very serious and also a delicate issue that happens day after day. In addition, we may even find it offensive to people who have suffered this type of abuse (Conclusions students group 1).

\section{The spanking by Alexis and Fido}

Big tits, big ass, morona, razona (...)

Run, hit it, whip it.

Whip it (Slow!)

Whip it (Slow!)

\begin{tabular}{|l|}
\hline Big tits, big ass, morona \\
\hline Pretty, Intelligent, affectionate \\
\hline
\end{tabular}

\begin{tabular}{|l|}
\hline Whip it (slow) \\
\hline Love it (slow) \\
\hline
\end{tabular}

In this song, the woman is discriminated against by referring to them by vulgar names. In addition, most of the lyrics use the verb "to whip" which, in our opinion, indicates a form of aggression towards women. (Conclusions students group 2)

\section{In Daddy Jankee's bed ft. Nicky Jam}

Look at that girl when we're going to strip her.

(...)

Pussy

Ass

Tit

She likes to be hit hard and eaten.

(...)

\begin{tabular}{|l|}
\hline Girl when we're going to strip her \\
\hline Girl when we're going to appreciate her \\
\hline
\end{tabular}

Throughout the song there are several sexual references. We don't think women should be seen as a sexual object. In addition to that in the songs we believe that saying words like "tits, ass ... "is not appropriate. (Conclusions 
students group 3)

\section{That in four is not seen by Lui $\mathbf{G}$}

She's a bit chubby but she gives good head

(...)

And whether she's skinny or fat, I don't care either.

The important thing is whether you suck or not

\begin{tabular}{|l|}
\hline She's a bit chubby but she gives good head \\
\hline She's beautiful but grumpy... \\
\hline
\end{tabular}

In this song we can see that the singer only sees women as a sexual object, because in the song he says: "And whether she's thin or fat I don't care either. The important thing here is whether she sucks or not". It is obvious that he doesn't care about the girl, nor about her appearance, he is only interested in having his sexual desires satisfied. (Conclusions students group 4).

\section{You're mine by Romeo Santos}

Because you're still mine (mine)

(...)

The selfishness of owning your life

You're mine (mine mine)

\begin{tabular}{|l|}
\hline Because you're still mine (mine) \\
\hline Because you're nobody's. \\
\hline
\end{tabular}

\begin{tabular}{|l|}
\hline The selfishness of owning your life \\
\hline The common sense of not owning anyone \\
\hline
\end{tabular}

He talks as if women were a property, an object. The singer says: "The selfishness of owning your life, you are mine (mine, mine)". He speaks as if he were the owner. We do not agree with this. The first reason is that women are not objects, but an independent being that does not belong to anyone and the second reason is that each person controls their own life; no one can own another person, because each individual is able to make their own decisions. (Conclusions students group 5).

\section{Lollypop by Kidd Jeo}

Put on work, I don't pay shit (I don't pay) (...)

Get on all fours, put it down and suck.

Not in the mouth, give it to me in the nape of my neck (slut).

\begin{tabular}{|l|}
\hline Get on all fours, put it down and suck. \\
\hline Stand up and fight \\
\hline
\end{tabular}

\begin{tabular}{|l|}
\hline Not in the mouth, give it to me in the nape of my neck (slut). \\
\hline Don't give me anything, because you don't owe me anything. \\
\hline
\end{tabular}

In this song, the singer refers to women as if they were prostitutes because he says: "put yourself to work, I don't pay for this". He also orders her to please him sexually and insults her. (Conclusions students group 6).

\section{Bitch by Elilluminari}

Crazy your wife is a bitch a devil

Look how she barks at me and tells me

Whoa, whoa, whoa.

(...) 
Your wife is a bitch.

(...)

\begin{tabular}{|l|}
\hline Your wife is a devil. \\
\hline Your wife is a saint. \\
\hline
\end{tabular}

\begin{tabular}{|l|}
\hline Your wife is a bitch. \\
\hline Your wife is a gift \\
\hline
\end{tabular}

\section{Four Babys by Maluma}

I don't know what to do anymore

I don't know which one to keep.

They all know how to mistreat me in bed.

They've got me good, they've got me good for sex.

I'm in love with four babies.

They always give me what I want

Live it up when I tell them

I don't get any, but

Two are married

There's a single woman

The other half psycho and if I don't call her

She despairs

\begin{tabular}{|l|}
\hline They always give me what I want \\
\hline They always give me what I deserve. \\
\hline
\end{tabular}

\begin{tabular}{|l|}
\hline I can't get any, but... \\
\hline They're all more than I deserve. \\
\hline
\end{tabular}

We think that the lyrics of this song are sexist because he says that he is in love with four "baby's" (that's how he refers to women). (Conclusions students group 7).

\section{If I behave badly by Dasoul}

And in the darkness

You want to know if what they're saying is true.

And she asks me for more

Even though I know I can hurt her.

It's not my fault if I misbehave.

We think these lyrics are sexist because he speaks about women as if they were an object and says that if he hurts her it is her own fault because he knows that he can hurt her. (Conclusions students group 8)

\begin{tabular}{|l|}
\hline Even though I know I can hurt her. \\
\hline Even though I know I won't be able to hurt her. \\
\hline
\end{tabular}

$$
\begin{aligned}
& \text { It's not my fault if I misbehave. } \\
& \text { It's not my fault if I love you too much. }
\end{aligned}
$$

\section{You're mine by Bad Bunny}


(...)

But you put pa'me (Aha)

Making them hate me more (Yeh-yeh-yeh)

Because everyone wants to try you $(A h)$

(...)

Tell him you're mine, mine

You know you're mine, mine

(...)

\begin{tabular}{|l|}
\hline Tell him you're mine \\
\hline Tell him you're nobody's. \\
\hline
\end{tabular}

\begin{tabular}{|l|}
\hline Because everyone wants to try you \\
\hline Because everyone looks at you badly. \\
\hline
\end{tabular}

\section{Conclusions}

Critical thinking and coeducation allow substantial changes and influences students' emotions and feelings. Fostering a critical spirit in adolescents is very important when facing the social changes that are necessary if we want to talk about education in terms of equality.

Teachers, educators and parents, aware of this reality, must train and provide their students with resources to foster this critical attitude towards certain musical styles, which are easy to listen but the message contained in most of them is sexist. This is what happens with most urban music, the reggaeton among them.

After the realization of this pedagogical proposal, a large number of adolescents have reported experiencing emotions of positive valence and active arousal. Nevertheless, they agree that after carrying out these activities and the subsequent discussion with the whole class they could feel a development of their critical spirit. Some even indicate that they feel emotions of negative valence (such as sadness or anguish) towards these kinds of songs.

After the critical analysis of the lyrics and the final debate, some students argue that: We think that most of these lyrics contain sexist messages because they insult women by calling them bitches several times. They also speak badly of the woman to her husband and refer to her as if she were below him.

Others affirm that we think the lyrics to these songs are very sexist because they say that the woman is their property and refer to her as an object, for example, in the Bad Bunny song, when he says that all men want to try her.

As a teacher and researcher, my opinion is that this pedagogical proposal has been very positive fundamentally because the students (who often listen, sing and watch urban music videos) on many occasions were not even aware of what they were singing or listening to. And I believe that, from this experience, at least a great majority of these students will be more aware of the sexual stereotypes that surround them and will be more critical when listening to and/or singing certain musical styles.

\section{References}

Adams, T., \& Fuller, D. (2006). The Words Have Changed But the Ideology Remains the Same: Misogynistic Lyrics in Rap Music. Journal of Black Studies, 36(6), 937-938. https://doi.org/10.1177/0021934704274072

Carpentier, F. D., Knobloch-Westerwick, S., \& Blumhoff, A. (2007). Naughty versus nice: Suggestive pop music influences on perceptions of potential romantic partners. Media Psychology, 9(1), 1-17. https://doi.org/10.1080/15213260709336800

Casey B.J., Giedd J.N., T. (2000). Structural and functional brain development and its relation to cognitive development. Biol Psychol, 54(1-3), 241-257. https://doi.org/10.1016/S0301-0511(00)00058-2

Contreras, P. y Trujillo, C. (2014). Coeducación para la equidad. A propósito del corpus curricular de la educación chilena. Análisis desde una perspectiva de género. Revista Universidad de León Cuestiones de género: de la igualdad y la diferencia, 9, 29-49. http://dx.doi.org/10.18002/cg.v0i9.1042

Edwards, R. \& Hodges, D. (2007). An overview of neuromusical research literature. In W. Gruhn, \& F. Rauscher (Eds.), Neurosciences in Music Pedagogy (pp. 1-25). New York: Nova Science Publications. 
Hyde, K., Lerch, J., Norton, A., Forgeard, M., Winner, E., Evans, A. C., \& Schlaug, G. (2009). Musical training shapes structural brain development. The Journal of Neuroscience, 26(10), 3019-3025. https://doi.org/10.1523/JNEUROSCI.5118-08.2009

Lamont, A, Webb, R. (2010). Short-and long-term musical preferences: what makes a favourite piece of music? Psychology of Music, 38(2), 222-241. https://doi.org/10.1177/0305735609339471

Miranda, D. (2012). The role of music in adolescent development: Much more than the same old song. Taylor\&Francis Online, 18(1), 5-22. https://doi.org/10.1080/02673843.2011.650182

North, A. C., \& Hargreaves, D. J. (1999). Music and adolescent identity. Music Education Research, $1,75-92$. https://doi.org/10.1080/1461380990010107

Oriola, S. y Gustems, J. (2015). Música y adolescencia: usos, funciones y consideraciones educativas. Universitas Tarraconensis, 2, 27-42. https://doi.org/10.17345/ute.2015.2.660

Simón, M. E. (2010). Aprende: Cuestión de coeducación. Madrid: Narcea Ediciones.

Strasburger, V. C. (1995). Adolescents and the Media. Medical and Psychological Impact. Developmental clinical psychology and psychiatry (Vol. 33). California: Thousand Oaks.

\section{Copyrights}

Copyright for this article is retained by the author(s), with first publication rights granted to the journal.

This is an open-access article distributed under the terms and conditions of the Creative Commons Attribution license (http://creativecommons.org/licenses/by/4.0/). 